\title{
The keratinolytic bacteria Bacillus cytotoxicus as a source of novel proteases and feather protein hydrolysates with antioxidant activities
}

\author{
Ivana Cavello* (1), Brenda Bezus (1) and Sebastián Cavalitto (1)
}

\begin{abstract}
Background: Argentina's geothermal areas are niches of a rich microbial diversity. In 2020, species of Bacillus cytotoxicus were isolated for the first time from these types of pristine natural areas. Bacillus cytotoxicus strains demonstrated the capability to grow and degrade chicken feathers with the concomitant production of proteases with keratinolytic activity, enzymes that have multitude of industrial applications. The aim of this research was to study the production of the proteolytic enzymes and its characterization. Also, feather protein hydrolysates produced during fermentation were characterized.

Results: Among the thermotolerant strains isolated from the Domuyo geothermal area (Neuquén province, Argentina), Bacillus cytotoxicus LT-1 and Oll-15 were selected and put through submerged cultures using feather wastes as sole carbon, nitrogen, and energy source in order to obtain proteolytic enzymes and protein hydrolysates. Complete degradation of feathers was achieved after $48 \mathrm{~h}$.

Zymograms demonstrated the presence of several proteolytic enzymes with an estimated molecular weight between 50 and $>120 \mathrm{kDa}$. Optimum pH and temperatures of Bacillus cytotoxicus LT-1 crude extract were 7.0 and $40^{\circ} \mathrm{C}$, meanwhile for OII-15 were 7.0 and $50^{\circ} \mathrm{C}$. Crude extracts were inhibited by EDTA and 1,10 phenanthroline indicating the presence of metalloproteases.

Feather protein hydrolysates showed an interesting antioxidant potential measured through radical-scavenging and $\mathrm{Fe}^{3+}$-reducing activities.
\end{abstract}

Conclusion: This work represents an initial approach on the study of the biotechnological potential of proteases produced by Bacillus cytotoxicus. The results demonstrated the importance of continuous search for new biocatalysts with new characteristics and enzymes to be able to cope with the demands in the market.

Keywords: Antioxidant activity, Bacillus cytotoxicus, Feather protein hydrolysate, Proteases, Thermotolerant bacteria

\footnotetext{
* Correspondence: icavello@biotec.quimica.unlp.edu.ar

Centro de Investigación y Desarrollo en Fermentaciones Industriales.

Facultad de Ciencias Exactas, Universidad Nacional de la Plata (CINDEFI,

CCT La Plata-CONICET, UNLP), Calle 47 y 115, (B1900ASH), La Plata, Argentina
}

\section{Springer Open}

(-) The Author(s). 2021 Open Access This article is licensed under a Creative Commons Attribution 4.0 International License, which permits use, sharing, adaptation, distribution and reproduction in any medium or format, as long as you give appropriate credit to the original author(s) and the source, provide a link to the Creative Commons licence, and indicate if changes were made. The images or other third party material in this article are included in the article's Creative Commons licence, unless indicated otherwise in a credit line to the material. If material is not included in the article's Creative Commons licence and your intended use is not permitted by statutory regulation or exceeds the permitted use, you will need to obtain permission directly from the copyright holder. To view a copy of this licence, visit http://creativecommons.org/licenses/by/4.0/. 


\section{Background}

Food industry, especially poultry industry, generates large quantities of feathers (organic wastes) which are mainly composed by keratin (almost 90\%). The growing intensity of this industrial activity leads to the accumulation of this kind of hard-to-degrade feather waste and causes a complete need for its disposal. Many countries have adopted the burning strategy, but it is highly polluting to the atmosphere. Alternatively, the production of feather meal by chemical treatment at high pressure can partially hydrolyze this recalcitrant protein, increasing the digestibility but reducing the amount of certain thermolabile amino acids, limiting its use as a livestock feed additive [1].

Microbial degradation has become the most suitable form of hydrolyzing this protein, offering an eco-friendly method, which is in concordance with the green practices that are necessary to adapt to protect the environment [1]. The bioconversion of feathers by keratinolytic microorganisms results in the production of enzymes such as keratinases and proteases, microbial biomass, and protein hydrolysates (with amino acids and peptides with bioactive properties). Keratinases and proteases are very useful for many industrial applications, especially on detergent industry, leather and textile industry, prion decontamination, and certain medical and cosmetic applications $[1,2]$.

The growing interest on the revalorization of feather waste to produce enzymes and protein hydrolysates reveals the need for further research, focusing on the search of enzyme systems to convert organic wastes into bioactive peptides which could be used for the formulation of novel bioproducts [3].

Although many proteases have been described from thermophilic and hyperthermophilic bacteria, only few thermophilic/thermotolerant bacteria are known to produce proteases with keratinolytic activity [4-9].

This study aimed to describe the production and characterization of the proteolytic extracts and the in vitro bioactive potentials of the culture supernatants produced by thermotolerant keratinolytic species of $B a-$ cillus cytotoxicus during submerged fermentation, with whole feathers as only carbon and nitrogen sources. As far as we know, this is the first approach to characterize the enzyme cocktail that these microorganisms produce.

\section{Methods}

\section{Microorganisms}

The strains Bacillus cytotoxicus LT- 1 and B. cytotoxicus Oll-15, previously isolated from samples collected from the hot springs of Los Tachos and Las Olletas in the Domuyo geothermal area, were used in this study. They are deposited on the Microbiological Culture Collection of CINDEFI-CONICET Institute, La Plata, Buenos Aires,
Argentina, and maintained on nutrient agar slants or glycerol stock $(20 \% \mathrm{w} / \mathrm{v})$ at 4 and $-80{ }^{\circ} \mathrm{C}$.

The strains were previously identified as $B$. cytotoxicus not only by their $16 \mathrm{~S}$ rRNA gene sequences but also by the amplification of $c y t K-1$ gene $[10,11]$.

\section{Growth conditions and protease production}

Submerged fermentations were performed using 250-ml Erlenmeyer flasks with $50 \mathrm{ml}$ of minimal mineral media (MMM) supplemented with $10 \mathrm{~g} \cdot \mathrm{l}^{-1}$ of whole chicken

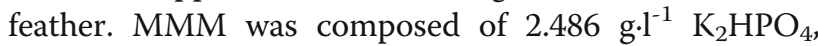
0.496 g. $l^{-1} \mathrm{NaH}_{2} \mathrm{PO}_{4}, 0.01 \mathrm{~g} \cdot \mathrm{l}^{-1} \mathrm{MgCl}_{2}, 0.016$ g. $\mathrm{l}^{-1} \mathrm{FeCl}_{3}$,

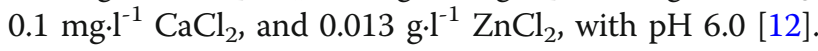
Chicken feathers were obtained from a local slaughterhouse and were washed with $0.1 \%(\mathrm{w} / \mathrm{v})$ sodium dodecyl sulfate (SDS) and with 1:1 (v/v) methanol and water with shaking for $18 \mathrm{~h}$ before use.

MMM supplemented with whole chicken feathers were inoculated with $1 \mathrm{ml}$ of a 24-h nutrient broth culture $\left(\mathrm{OD}_{\mathrm{i}} 6000.5\right)$ of each bacterial strain and incubated at $50{ }^{\circ} \mathrm{C}, 150 \mathrm{rpm}$ for 2 days. Samples were withdrawn in sterile conditions periodically. Biomass and other residues were separated by centrifugation at $10,000 \times g$ for $10 \mathrm{~min}$ at $4{ }^{\circ} \mathrm{C}$, and supernatants were used as crude extracts for the subsequent analysis.

\section{Production of feather protein hydrolysates (FPHs)}

FPHs were obtained inoculating the bacterial strains on MMM supplemented with $10 \mathrm{~g} \cdot \mathrm{l}^{-1}$ of whole chicken feathers and incubating them at $50{ }^{\circ} \mathrm{C}, 150 \mathrm{rpm}$ until feather degradation was completed ( 2 days). Then, cultures were centrifuged at $6000 \times g$ for 15 min, filtered through a $0.54-\mu \mathrm{m}$ cellulose acetate filter, and the supernatants were preserved at $-20{ }^{\circ} \mathrm{C}$ until the performance of antioxidant assays.

\section{Enzyme activity}

Proteolytic activity was determined using azocasein (Sigma Co., USA) as substrate following the protocol described by Cavello et al. [12]. Briefly, $100 \mu$ of suitable dilution of each enzyme preparation were added to 250 $\mu \mathrm{l}$ of the substrate $\left(10 \mathrm{~g} \cdot \mathrm{l}^{-1}\right.$, Tris- $\mathrm{HCl}$ buffer $20 \mathrm{mM}$; pH 7.0). The admixture was incubated for $1 \mathrm{~h}$ at $50{ }^{\circ} \mathrm{C}$, and after that, the reaction was stopped by the addition of 1 $\mathrm{ml}$ of trichloroacetic acid (TCA; 10\%, w/v). After centrifugation $\left(10,000 \times g\right.$ for $\left.15 \mathrm{~min}, 4{ }^{\circ} \mathrm{C}\right)$, equal volumes of the supernatant and $\mathrm{NaOH}(1.0 \mathrm{M})$ were mixed. The absorbance at $440 \mathrm{~nm}$ was measured. Blanks were performed for each reaction. One unit $(\mathrm{U})$ of protease activity was defined as the amount of enzyme that produced an increase in 0.01 absorbance units under the experimental assay conditions described [12]. 


\section{Protein determination}

The protein concentration of the samples were performed by the Bradford method [13], using bovine serum albumin (SIGMA) as standard.

\section{Effect of $\mathrm{pH}$ on the enzyme activity}

Optimum $\mathrm{pH}$ was determined by incubating each enzymatic extract with azocasein as substrate at different pH levels (6.0-12.0, MES-Tris-Glycine buffers $20 \mathrm{mM}$ each). After $1 \mathrm{~h}$ of incubation at $50{ }^{\circ} \mathrm{C}$, residual activity was performed, and percentage relative activity was calculated considering $100 \%$ of the activity was displayed with the optimum $\mathrm{pH}$.

\section{Effect of temperature on the activity and stability}

Effect of temperature on enzyme activity was studied by incubating the reaction admixture (enzyme + substrate) at different temperatures $\left(20-80{ }^{\circ} \mathrm{C}\right)$. Enzyme activity has been expressed as percentage relative activity.

Activation energies (Ea) of the enzymes were calculated by plotting the residual activity after the incubation at different temperatures according to the linearized Arrhenius equation (1):

$$
\ln K=\frac{E a}{R} \frac{1}{T}+\ln A,
$$

where $K$ is the enzymatic activity rate at the correspondent temperature ( $T$, in Kelvins), Ea is the activation energy, $R$ is the gas constant $\left(8.314 \mathrm{~J} \cdot \mathrm{K}^{-1} \cdot \mathrm{mol}^{-1}\right)$, and $A$ is a constant.

Thermal stability was determined by incubating the extracts at different temperatures between 30 and $50{ }^{\circ} \mathrm{C}$. Aliquots were withdrawn at different times, and residual activities were measured considering 100\% of activity was displayed by the non-treated enzyme.

\section{Effect of protease inhibitors, metal ions, and organic solvents on protease activity}

The nature of the proteases present on the enzymatic extracts was studied by evaluating the effect of different protease inhibitors: phenylmethylsulfonyl fluoride (PMSF, $1 \mathrm{mM}$ ), ethylenediaminetetraacetic acid (EDTA, $1 \mathrm{mM}), 1,10$-phenanthroline $(1 \mathrm{mM})$, iodoacetamide (1 $\mathrm{mM})$, and pepstatin $\mathrm{A}(5 \mu \mathrm{M})$. Extracts were incubated with each inhibitor separately for $1 \mathrm{~h}$ at $20{ }^{\circ} \mathrm{C}$, and after that, standard assay of proteolytic activity was performed. The activity obtained by the enzyme without any inhibitor-incubation was taken as $100 \%$ of activity.

The effect of different metal ions $\left(\mathrm{MgCl}_{2}, \mathrm{CoCl}_{2}\right.$, $\mathrm{CaCl}_{2}, \mathrm{MnCl}_{2}, \mathrm{ZnCl}_{2}, \mathrm{NaCl}, \mathrm{KCl}$, and $\mathrm{HgCl}_{2}, 1 \mathrm{mM}$ ) on the enzymatic activity was evaluated incubating each extract for $60 \mathrm{~min}$ at $20{ }^{\circ} \mathrm{C}$. After that, the residual activity was determined, and the activity of the enzyme without metal ion was considered as $100 \%$.

Concerning to the effect of some organic solvents on enzyme activity, methanol, ethanol, and isopropanol ( $1 \%$ $\mathrm{v} / \mathrm{v}$ ) were incubated with extracts for an hour at $20{ }^{\circ} \mathrm{C}$. After that, the residual enzymatic activity was determined and expressed as a percentage of the nonincubated enzyme.

\section{Stability and compatibility with laundry detergents}

Stability and compatibility of B. cytotoxicus extracts with solid (Drive, Ariel, Ace or Skip, $7 \mathrm{mg} \cdot \mathrm{l}^{-1}$ ) and liquid (Ace, Ala, Ariel, or Skip, 1\% v/v) laundry detergents were studied, preincubating each laundry detergent with each enzymatic extract for $1 \mathrm{~h}$ at room temperature. After incubation, the remaining activity was determined under standard assay conditions, and residual activity was calculated considering $100 \%$ of the activity was displayed by the enzyme incubated without the addition of any detergent. Before the assay, endogenous enzymes present on the commercial detergents were inactivated by a heat treatment of $65^{\circ} \mathrm{C}$ for $1 \mathrm{~h}$.

\section{Sodium dodecyl sulfate polyacrylamide gel} electrophoresis (SDS-PAGE) and zymogram

SDS-PAGE coupled to a zymogram was performed as described before by García-Carreño et al. [14], with some modifications. A $5 \% \mathrm{w} / \mathrm{v}$ stacking gel and $12 \% \mathrm{w} / \mathrm{v}$ separating gel were prepared as described by Laemmli [15]. To carry out the zymogram, after electrophoresis, SDS was removed from the gel flooding it with a solution of Triton X-100 (2.5\% w/v Tris- $\mathrm{HCl} 20 \mathrm{mM} \mathrm{pH}$ 7.0) under agitation for $1 \mathrm{~h}$. Then, the gel was washed three times with Tris- $\mathrm{HCl} 20 \mathrm{mM}$ and incubated with casein $10.00 \mathrm{~g} \cdot \mathrm{l}^{-1}$ for $1 \mathrm{~h}$ at $50{ }^{\circ} \mathrm{C}$. After incubation, the gel was stained with Coomassie Brilliant Blue G-250 following the Coomassie Colloidal method [16]. The presence of protease activity was evidenced by a clear zone in a blue background. For the SDS-PAGE, a broad range molecular weight marker was used (Thermo Fisher Scientific, \#26612).

\section{Antioxidant activity Reducing power assay}

To determine the ability of the feather protein hydrolysates to reduce Fe (III), $100 \mu \mathrm{l}$ of sample were incubated with $250 \mu$ of phosphate buffer $(0.2 \mathrm{M}, \mathrm{pH}$ 6.6) and 250 $\mu \mathrm{l}$ of $\mathrm{K}_{3} \mathrm{Fe}(\mathrm{CN})_{6} 3 \mathrm{H}_{2} \mathrm{O} 10.00 \mathrm{~g} \cdot \mathrm{l}^{-1}$ at $50{ }^{\circ} \mathrm{C}$ for $30 \mathrm{~min}$. After that, $250 \mu \mathrm{l}$ of $10 \% \mathrm{w} / \mathrm{v}$ TCA were added. The admixture was centrifuged at $16,000 \times g$ for $10 \mathrm{~min}$, and $250 \mu \mathrm{l}$ of the supernatant was mixed with $250 \mu \mathrm{l}$ of water and $50 \mu \mathrm{l}$ of $\mathrm{FeCl}_{3}(0.1 \% \mathrm{w} / \mathrm{v})$. After $10 \mathrm{~min}$, absorbance at $700 \mathrm{~nm}$ was measured, and reducing power was identified in samples that produced an increase of 
the absorbance. Results were expressed as absorbance at $700 \mathrm{~nm}$. As positive control, the reducing power of ascorbic acid was also determined $\left(0-3.0 \mathrm{~g} \cdot \mathrm{l}^{-1}\right)$. Blanks were performed using not inoculated media instead of FPH [17].

\section{ABTS radical scavenging activity}

ABTS (2,20-azino-bis-(3-ethylbenzothiazoline)-6-sulfonic acid) radical cation $\left(\mathrm{ABTS}^{*+}\right)$ was produced by reacting ABTS stock solution (3.60 g. $\mathrm{l}^{-1}$ ) with potassium persulfate $\left(0.66 \mathrm{~g} \cdot \mathrm{l}^{-1}\right)$ allowing the mixture to stand in the dark for at least $12 \mathrm{~h}$ at $20^{\circ} \mathrm{C}$ before use [18]. For the assay, a fresh solution of $\mathrm{ABTS}^{\prime \prime+}$ was prepared by dilution with $5 \mathrm{mM}$ phosphate-buffered saline (PBS, pH 7.4) to reach an absorbance of $0.7 \pm 0.05$ at $734 \mathrm{~nm}$. Sample $(10 \mu \mathrm{l})$ was mixed with $\mathrm{ABTS}^{*+}$ solution $(1 \mathrm{ml})$, and the absorbance $(734 \mathrm{~nm})$ was taken after 4 min of reaction. A calibration curve with Trolox (6-Hydroxy2,5,7,8-tetramethylchromane-2-carboxylic acid) was performed $(0-5.0 \mathrm{mM})$. Results were expressed as the milliequivalents $(\mathrm{mEq})$ of Trolox displayed per gram of feather protein hydrolysate.

The radical scavenging activity of the sample was calculated as shown in equation 2:

$$
\begin{aligned}
& \text { ABTS radical scavenging activity }(\%) \\
& =\frac{A_{B}-A_{S}}{A_{B}} \times 100
\end{aligned}
$$

where $A_{B}$ is the absorbance at $734 \mathrm{~nm}$ of the blank, and $A_{S}$ is the absorbance at $734 \mathrm{~nm}$ of the sample reaction. Blank reactions were performed using noninoculated media instead of FPH.

Half maximal effective concentration $\left(\mathrm{EC}_{50}\right)$ values were calculated from the percentage radical scavenging against FPH concentration plots and represent the concentration of $\mathrm{FPH}$ resulting in 50\% radical scavenging.

\section{Nucleotide sequence accession number}

Sequences of $16 \mathrm{~S}$ rRNA gene of strains LT- 1 and Oll-15 are deposited in the GenBank database under accession numbers KR559937 and KR559942, respectively [11].

\section{Statistical analysis}

Results were expressed as an average of three independent experiments with the correspondent standard deviation. $P$ values less or equal to 0.05 were considered as statistically significant (LSD test of ANOVA).

\section{Results}

\section{Microorganisms}

In the southwest of Argentina, there are two volcanic geothermal areas: Copahue and Domuyo. Prokaryotic biodiversity and the biotechnological applications of some of the species isolated in Copahue have been quite studied; meanwhile, the Domuyo geothermal area remains almost unexplored in these aspects [19-23].

It is in the Domuyo geothermal area that several strains of Bacillus cytotoxicus were isolated and characterized, a novel keratinolytic bacteria isolated for the first time from pristine environments. Among the collection of B. cytotoxicus strains, B. cytotoxicus LT-1 and B. cytotoxicus Oll-15 were selected due to its capability to grow and degrade whole chicken feathers on a minimal mineral media after only $24-48 \mathrm{~h}$ of cultivation at $50{ }^{\circ} \mathrm{C}$ [11].

\section{Protease production}

Time course production of proteases is presented in Fig. 1. Bacillus cytotoxicus Oll-15 under the described fermentation conditions reached a maximum enzyme production of $14.4 \pm 0.2 \mathrm{U} \cdot \mathrm{ml}^{-1}$ in $24 \mathrm{~h}$ of incubation, while strain LT-1 reached a maximum of $16.6 \pm 0.4$ $\mathrm{U} \cdot \mathrm{ml}^{-1}$ after $33 \mathrm{~h}$ of cultivation.

\section{Effect of $\mathrm{pH}$ on the activity}

The study on the effect of $\mathrm{pH}$ on the enzymatic activity demonstrated that both proteolytic extracts displayed optimum activity at neutral $\mathrm{pH}$ (pH 7.0, Fig. 2). It can be seen as a considerable residual activity in the range of pH 6.0-8.0 (higher than 69\% for Oll-15 and 92\% for LT1 , respectively). A decrease in residual activity at $\mathrm{pH}$ higher than 9.0 was observed for both enzymatic extracts.

\section{Effect of temperature on the activity and stability}

Regarding the optimum temperature for proteolytic activity, it could be seen that Bacillus cytotoxicus' enzymatic extracts differ from each other. B. cytotoxicus LT-1 proteolytic extract displayed an optimum temperature of $50{ }^{\circ} \mathrm{C}$, while B. cytotoxicus Oll-15 displayed an optimum temperature of $40{ }^{\circ} \mathrm{C}$. At $60{ }^{\circ} \mathrm{C}$, both extracts presented a considerably low relative activity $(12 \%$ and $10 \%$ for LT-1 and Oll-15, respectively), and no activity was detected above $60{ }^{\circ} \mathrm{C}$ (Fig. 3a).

Activation energies for the reaction were calculated using the Arrhenius plot and resulted in $56.66 \mathrm{KJ} / \mathrm{mol}$ for LT-1 enzyme cocktail and $70.69 \mathrm{KJ} / \mathrm{mol}$ for Oll-15 enzyme cocktail, respectively (Fig. 3b).

Thermostability study showed that Bacillus cytotoxicus LT-1 and Oll-15 proteolytic extracts were completely stable up to $45{ }^{\circ} \mathrm{C}$ and retained approximately $66.5 \%$ and $71.3 \%$ of their activity at $50{ }^{\circ} \mathrm{C}$ after $60 \mathrm{~min}$ of incubation (Fig. 3c). The half-life times of LT-1 and Oll-15 extracts were 99 and $115.5 \mathrm{~min}$, respectively at $50{ }^{\circ} \mathrm{C}$. It was observed that at $60{ }^{\circ} \mathrm{C}$, both extracts were rapidly denatured, and no activity was detected after $15 \mathrm{~min}$ of incubation. 


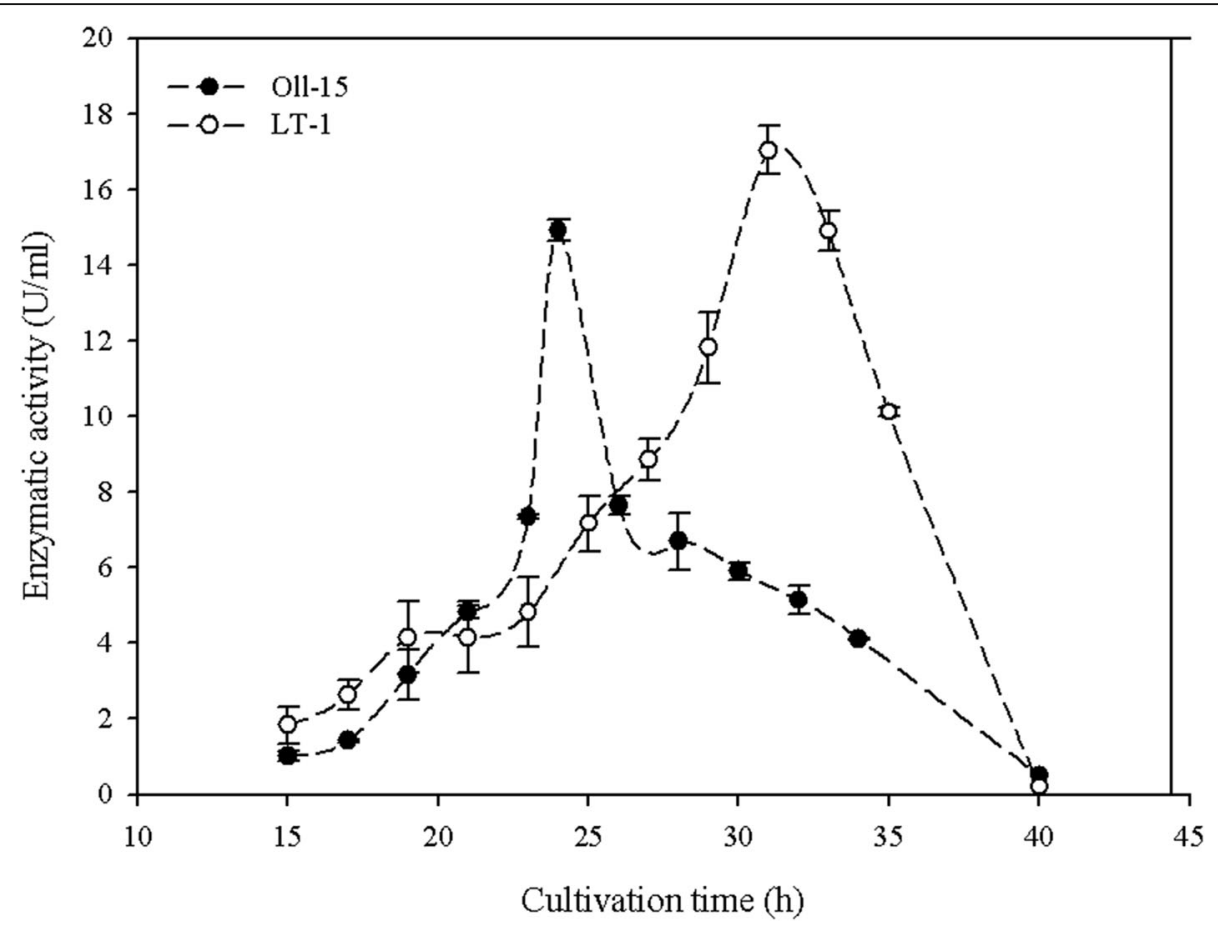

Fig. 1 Keratinolytic protease production profiles of B. citotoxycus strains. Strains were incubated in MMM supplemented with $10 \mathrm{~g} \cdot \mathrm{l}^{-1}$ of whole feather at $50{ }^{\circ} \mathrm{C}$ for $48 \mathrm{~h}$

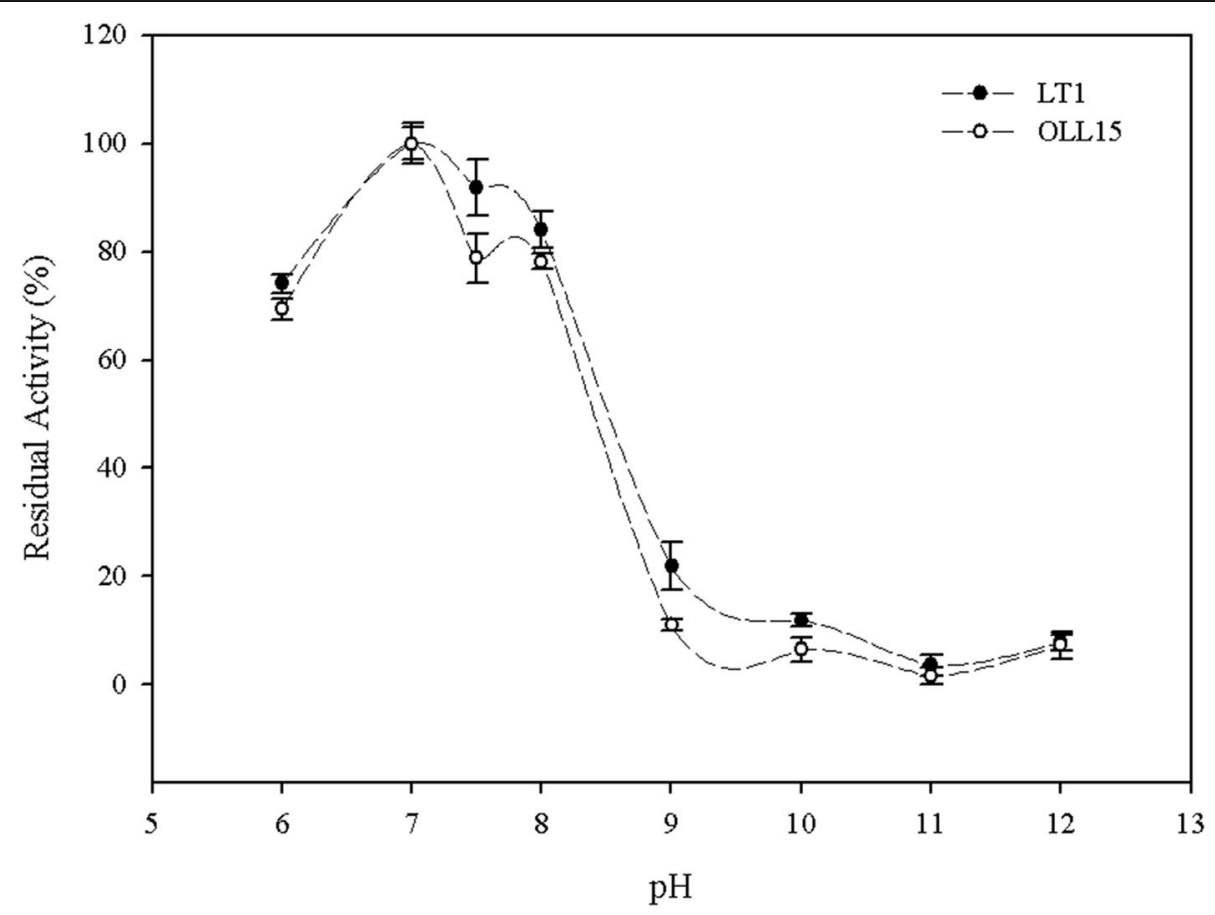

Fig. 2 Effect of pH on the activity of proteolytic extracts obtained with Bacillus cytotoxicus LT-1 and Bacillus cytotoxicus Oll-15. Each determination was performed in triplicates, and values represent mean \pm SD 

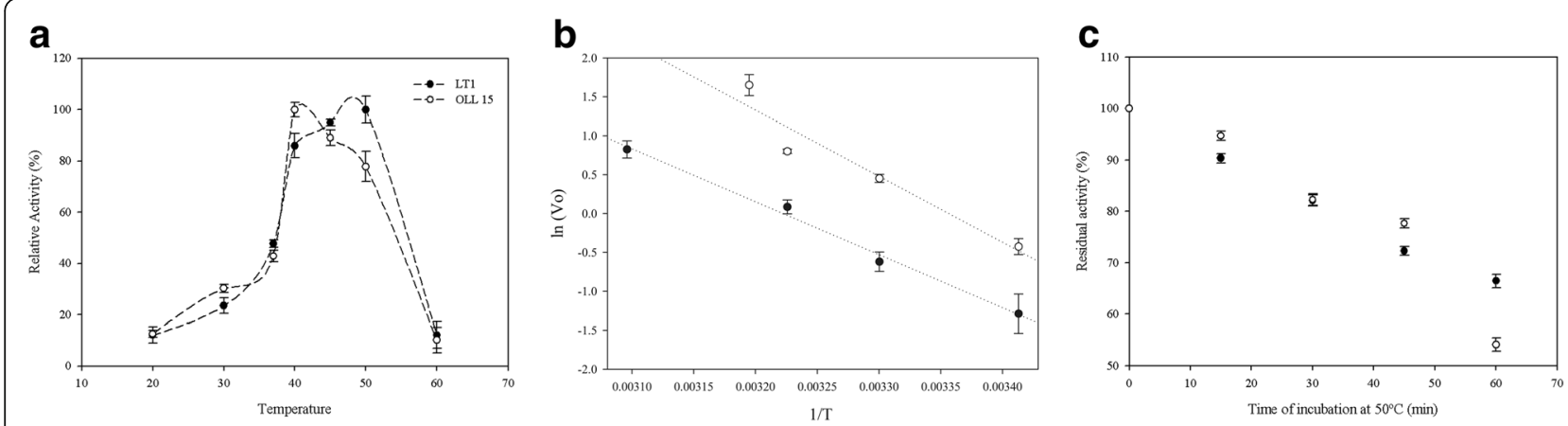

Fig. 3 a Effect of the temperature on the activity of the keratinolytic extracts obtained with Bacillus cytotoxicus LT-1 and Bacillus cytotoxicus Oll-15. b Arrhenius plot obtained by plotting the logarithm of enzymatic activity (Vo) versus inverse of temperature (1/T, in Kelvins); LT-1 (black) and OII15 (white). c Effect of temperature on enzyme stability. Residual activity in function of time incubation at $50{ }^{\circ} \mathrm{C}$. Each determination was performed in triplicates, and values represent mean \pm SD

\section{Effect of chemicals on proteolytic activity}

Proteolytic activity of B. cytotoxicus extracts were completely inhibited by EDTA and 1,10 phenanthroline indicating that proteolytic enzymes present in these extracts belong to the group of metalloproteases (Table 1). Regarding the effect of certain organic solvents, they slightly inhibited the activity of the extracts. The presence of ethanol reduced the LT-1 activity by $13 \%$ and did not affect Oll-15 activity. Isopropanol produced an inhibition between 13 and 15\%. Methanol did not affect the activity in neither of the extracts.

The effect of different metal ions is shown in Table 1. Divalent cations $\mathrm{Ca}^{+2}, \mathrm{Mg}^{+2}, \mathrm{Mn}^{+2}$, and $\mathrm{Zn}^{+2}$ increased protease activity by $143.8,121.8,117.5$, and $107.5 \%$ for LT-1, respectively, and by 147.2, 130.1, 116.2, and $112.2 \%$ for Oll-15, respectively.

\section{SDS-PAGE and zymogram}

An SDS-PAGE coupled to a casein zymogram was performed in order to estimate the molecular weight of the proteases present in the extracts (Fig. 4). At least three different proteolytic bands were visualized on the LT-1 zymogram (Lane 2), two of them with apparent molecular weights between 50 and $85 \mathrm{kDa}$ and one band with a molecular weight higher than $120 \mathrm{kDa}$. The zymogram of the crude extract of Oll-15 showed a similar proteolytic composition, but with an additional band slightly over $50 \mathrm{kDa}$ (Lane 3).

\section{Stability and compatibility with commercial laundry detergents}

The data presented in Table 1 show that although both enzymatic extracts lost a considerable amount of activity when they were incubated with commercial detergents, it is worthy to mention that B. cytotoxicus LT-1 proteases retained $45.3 \%$ residual activity after $1 \mathrm{~h}$ of incubation in Ala and $42.3 \%$ in Ace, both liquid detergents, while the maximum stability for B. cytotoxicus Oll-15 was observed with the solid detergent Ace (39.1\%).

\section{Bioactivities of FPHs: characterizations of the feather protein hydrolysates}

We explore the antioxidant activity of the FPHs obtained by the action of the proteases of B. cytotoxicus LT-1 and Oll-15 by two in vitro methods: the reducing power of $\mathrm{Fe}^{+3}$ and the radical scavenging activity assays (ABTS assay). In general, dose-dependent responses were observed, and an increase of FPH concentrations resulted in enhanced bioactive potentials.

The FPH obtained from B. cytotoxicus LT-1 biodegradation did not show an appreciable activity of reducing power, while the FPH from B. cytotoxicus Oll-15 biodegradation (protein concentration: $0.27 \mathrm{mg} \cdot \mathrm{ml}^{-1}$ ) produced an absorbance $(700 \mathrm{~nm})$ of 0.86 , similar to that obtained by a solution of $0.25 \mathrm{mg} \cdot \mathrm{ml}^{-1}$ of ascorbic acid $\left(\mathrm{Abs}_{700}\right.$ 0.83, Fig. 5a).

Regarding ABTS radical scavenging activity, both LT-1 and Oll-15 FPHs demonstrated a considerable antioxidant activity: 10.17 and $11.74 \mathrm{mEq}$ of Trolox/g of protein, respectively. In terms of scavenging activity, the activity obtained by the extracts was $85 \%$ and $64 \%(0.41$ $\mathrm{mg} \cdot \mathrm{ml}^{-1}$ of protein from Oll-15 $\mathrm{FPH}$ and $0.24 \mathrm{mg} \cdot \mathrm{ml}^{-1}$ of protein from LT-1 FPH, respectively, Fig. $5 \mathrm{~b}$ ).

The $\mathrm{EC}_{50}$ values were calculated from the dose-response curves being $0.16 \mathrm{mg} \cdot \mathrm{ml}^{-1}$ for FPH obtained with B. cytotoxicus Oll-15 and $0.22 \mathrm{mg} \cdot \mathrm{ml}^{-1}$ for FPH obtained with B. cytotoxicus LT-1.

\section{Discussion}

As a proteolytic/keratinolytic enzyme producer, Bacillus is one of the most studied genera. Their keratinolytic proteases have been studied since 1990 when Bacillus licheniformis PWD-1-a feather-degrading bacterium isolated from a thermophilic poultry waste digestorwas reported [24]. At $50{ }^{\circ} \mathrm{C}$, a complete degradation of 
Table 1 Effect of protease inhibitors, organic solvents, metal ions, and detergents on the activity of the keratinolytic extracts obtained with Bacillus cytotoxicus LT-1 and Bacillus cytotoxicus Oll-15. Each determination was performed in triplicate. Residual activity is expressed as a percentage, comparing with the activity measured in the absence of any compound. Asterisks show the differences with a $P<0.05$ (LSD test, ANOVA).

\begin{tabular}{|c|c|c|c|}
\hline \multirow[t]{2}{*}{ Chemical } & \multirow[t]{2}{*}{ Concentration } & \multicolumn{2}{|c|}{ Residual activity (\%) } \\
\hline & & LT-1 & Oll-15 \\
\hline \multicolumn{4}{|l|}{ Inhibitors } \\
\hline PMSF & $1 \mathrm{mM}$ & $87.8 \pm 3.0^{*}$ & $95.8 \pm 4.4^{*}$ \\
\hline lodoacetamide & $1 \mathrm{mM}$ & $89.7 \pm 4.2^{*}$ & $56.9 \pm 3.2^{*}$ \\
\hline EDTA & $1 \mathrm{mM}$ & $4.5 \pm 1.9^{*}$ & $0.6 \pm 0.1^{*}$ \\
\hline Phenantroline & $1 \mathrm{mM}$ & $1.8 \pm 0.5^{*}$ & $0.8 \pm 0.5^{*}$ \\
\hline Pepstatin A & $5 \mu \mathrm{M}$ & $98.5 \pm 1.2$ & $111.1 \pm 0.4^{*}$ \\
\hline \multicolumn{4}{|l|}{ Metal ions } \\
\hline $\mathrm{Mg}^{+2}$ & $1 \mathrm{mM}$ & $121.8 \pm 2.2^{*}$ & $130.1 \pm 2.9^{*}$ \\
\hline $\mathrm{Zn}^{+2}$ & $1 \mathrm{mM}$ & $107.5 \pm 5.3^{*}$ & $112.2 \pm 10.0^{*}$ \\
\hline $\mathrm{Ca}^{+2}$ & $1 \mathrm{mM}$ & $143.8 \pm 2.3^{*}$ & $147.2 \pm 0.8^{*}$ \\
\hline $\mathrm{Mn}^{+2}$ & $1 \mathrm{mM}$ & $117.5 \pm 3.1^{*}$ & $116.2 \pm 13.8^{*}$ \\
\hline $\mathrm{CO}^{+2}$ & $1 \mathrm{mM}$ & $41.3 \pm 4.4^{*}$ & $46.4 \pm 3.3^{*}$ \\
\hline $\mathrm{Na}^{+}$ & $1 \mathrm{mM}$ & $94.9 \pm 6.7$ & $82.7 \pm 6.5^{*}$ \\
\hline $\mathrm{K}^{+}$ & $1 \mathrm{mM}$ & $89.1 \pm 4.2^{*}$ & $107.1 \pm 6.4$ \\
\hline $\mathrm{Hg}^{+2}$ & $1 \mathrm{mM}$ & $28.5 \pm 3.1^{*}$ & $27.9 \pm 2.3^{*}$ \\
\hline \multicolumn{4}{|l|}{ Organic solvents } \\
\hline Methanol & $1 \% \mathrm{v} / \mathrm{v}$ & $98.3 \pm 1.5$ & $102.6 \pm 1.7$ \\
\hline Ethanol & $1 \% \mathrm{v} / \mathrm{v}$ & $87.4 \pm 3.7^{*}$ & $97.8 \pm 2.7$ \\
\hline Isopropanol & $1 \% \mathrm{v} / \mathrm{v}$ & $84.9 \pm 0.7^{*}$ & $87.3 \pm 1.2^{*}$ \\
\hline \multicolumn{4}{|c|}{ Commercial detergents } \\
\hline Ala & $1 \% \mathrm{v} / \mathrm{v}$ & $45.3 \pm 3.2^{*}$ & $9.0 \pm 1.1^{*}$ \\
\hline Ariel & $1 \% \mathrm{v} / \mathrm{v}$ & $15.9 \pm 1.4^{*}$ & $17.8 \pm 6.6^{*}$ \\
\hline Ace & $1 \% \mathrm{v} / \mathrm{v}^{-}$ & $42.3 \pm 2.1^{*}$ & $1.9 \pm 1.5^{*}$ \\
\hline Skip & $1 \% \mathrm{v} / \mathrm{v}$ & $20.1 \pm 1.1^{*}$ & $1.2 \pm 2.1^{*}$ \\
\hline Drive & $7 \mathrm{mg} \mathrm{I}^{-1}$ & $9.3 \pm 1.5^{*}$ & $5.0 \pm 1.5^{*}$ \\
\hline Ariel & $7 \mathrm{mg} \cdot \mathrm{l}^{-1}$ & $4.1 \pm 1.2^{*}$ & $2.0 \pm 0.7^{*}$ \\
\hline Ace & $7 \mathrm{mg} \cdot \mathrm{I}^{-1}$ & $10.7 \pm 1.4^{*}$ & $39.1 \pm 1.5^{*}$ \\
\hline Skip & $7 \mathrm{mg} \cdot \mathrm{l}^{-1}$ & $4.7 \pm 1.3^{*}$ & $2.1 \pm 0.6^{*}$ \\
\hline
\end{tabular}

keratin protein by $B$. licheniformis PWD-1 was observed after 7 to 10 days [24]. Although keratinolytic proteases have been studied since 90s, keratinases from thermophilic or thermotolerant Bacillus is not common, being the list of this type of keratinolytic microorganisms quite short. B. licheniformis K-508 [25], B. subtilis RM-01 [26], Brevibacillus thermoruber T1E [27], and B. halodurans JB99 [28] are representatives of this group of microorganisms.

Our work has the aim to enlarge the list of these moderate extremophiles studying the production and characterization of the proteolytic enzymes produce by novel strains of the thermotolerant keratinolytic bacteria: Bacillus cytotoxicus. Bacillus cytotoxicus strains have been isolated for the first time from pristine areas in 2020 [11].

Under submerged fermentation with feathers as only source of carbon and nitrogen, the maximum enzyme activity was reached after $24-33 \mathrm{~h}$ for B. cytotoxicus Oll15 and LT-1, respectively at $50{ }^{\circ} \mathrm{C}$. This agrees with Bouacem et al. [29] who reported the thermophilic bacteria Caldicoprobacter algeriensis isolated from hot spring, which produced $21.0 \mathrm{U} / \mathrm{ml}$ at $50{ }^{\circ} \mathrm{C}$ after $24 \mathrm{~h}$ of incubation. The mesophilic B. cereus LAU08 and TS1 had an optimum incubation time of 48 and $72 \mathrm{~h}$, respectively [30, 31]. Meanwhile, enzyme productions by B. pumilus A1 [32] and B. weihenstephaensis PKD5 [33] had optimum incubation periods of 4 and 7 days, respectively.

Regarding the biochemical characterization it could be said that, in general, Bacillus' proteases-with keratinolytic activity-showed basic optimum $\mathrm{pHs}$ in the range of 8.0-9.0 (i.e., B. subtilis, B. licheniformis ALW1, and B. pumilus FH9) [34-37]. B. amyloliquefaciens S13 and Bacillus sp. P45 keratinolytic crude proteases are examples of those that showed an optimum $\mathrm{pH}$ in the neutral range (6.5-7.0) [36]. Higher optimum $\mathrm{pH}$ values were generally observed on thermophilic and thermotolerant proteases. Thermoanaerobacter sp. 1004-09, Streptomyces sp. AB1, and Actinomadura keratinolytica Cpt29 keratinases have alkaline optimum $\mathrm{pHs}$ in the range of 9.0 to $11.5[7,38,39]$. Clostridium PE's keratinase also showed an optimum $\mathrm{pH}$ in a neutral to alkaline range, between 7.0 and 9.0 [8].

Bacillus cytotoxicus crude extracts present optimum temperatures that are in concordance with other proteases with keratinolytic activity from the genera Bacillus. Usually, these enzymes displayed optimum temperatures in the range of 50 to $60{ }^{\circ} \mathrm{C}$. B. licheniformis ALW1 produced a keratinase which was reported to have an optimum temperature of reaction of $65{ }^{\circ} \mathrm{C}$ [40]. Cai et al. [34] purified a keratinase produced by $B$. subtilis $\mathrm{KD}-\mathrm{N} 2$, with an optimum temperature of $55{ }^{\circ} \mathrm{C}$. Hamiche et al. [36] and Abdel-Naby et al. [35] studied keratinases from B. amyloliquefaciens S13 and B. pumilus FH9, reporting its optimum temperatures between 50 and $60{ }^{\circ} \mathrm{C}$. Bacillus sp. P45 crude keratinolytic protease displayed optimum activity at $50{ }^{\circ} \mathrm{C}$ [41]. Bacillus aerius NSMk2 keratinase showed optimum activity at 45 ${ }^{\circ} \mathrm{C}$ [42], while the optimum temperature for Bacillus subtilis NRC3 keratinase was $40{ }^{\circ} \mathrm{C}$ [43].

Activation energies calculated for both extracts are in concordance with their thermotolerant characteristic, being higher than other results obtained from nonthermotolerant proteases. Higher free energies of 


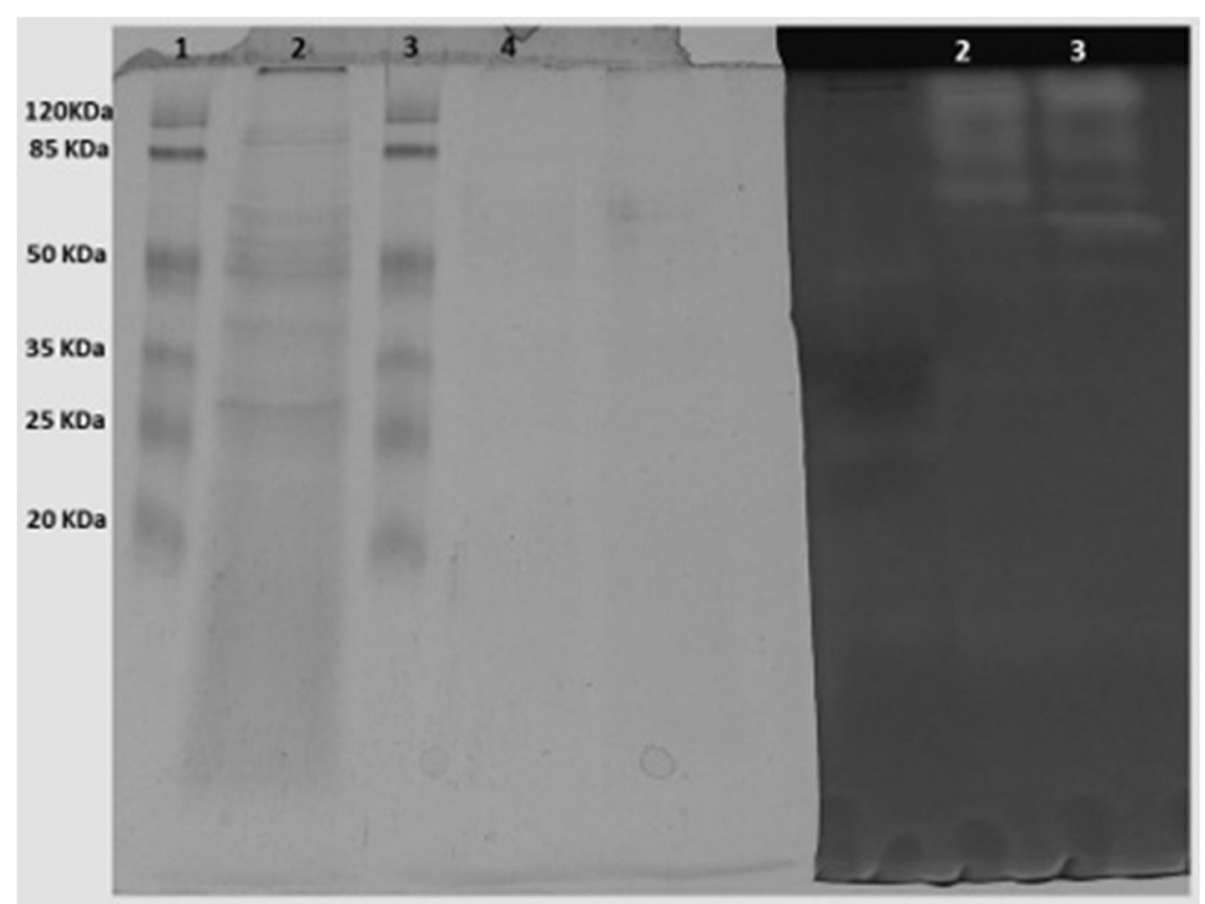

Fig. 4 SDS-PAGE (left) and Zymogram (right) of the keratinolytic extracts. From left to right: molecular weight marker (lane 1), LT-1 crude extract (lane 2), molecular weight marker (lane 3), Oll-15 crude extract (lane 4). Zymogram: LT-1 crude extract (lane 1) and Oll-15 crude extract (lane 2)

activation and decrease in the unfolding rate are cited as mechanisms of adaptation, mainly on thermophilic and hyperthermophilic proteins [44]. Abdel-Naby et al. [35] and Hashem et al. [45] reported activation energies of 24 $\mathrm{KJ} / \mathrm{mol}$ and $25.3 \mathrm{KJ} / \mathrm{mol}$ for the proteases with keratinolytic activity from the mesophylls $B$. pumilus FH9 and $B$. licheniformis ALW1.

Thermal stability of proteolytic extracts of B. cytotoxicus strains was a common feature that it is observed among Bacillus sp. Proteases and keratinases. B. invictae enzymatic preparation retained $94 \%$ of its original activity after $60 \mathrm{~min}$ at $50{ }^{\circ} \mathrm{C}$ [46]. In the case of $B$. subtilis FTC02PR1 keratinolytic enzymes showed a rapid activity loss after incubation for $15 \mathrm{~min}$ at $55{ }^{\circ} \mathrm{C}$ [47]. In addition, Gegeckas et al. [48] reported that the half-life time of BPKer from Bacillus sp. AD-W was $44 \mathrm{~min}$ at $50{ }^{\circ} \mathrm{C}$, while the keratinase produced by $B$. licheniformis ALW1 had a half-life of $2 \mathrm{~h}$ at $60{ }^{\circ} \mathrm{C}$ [40].
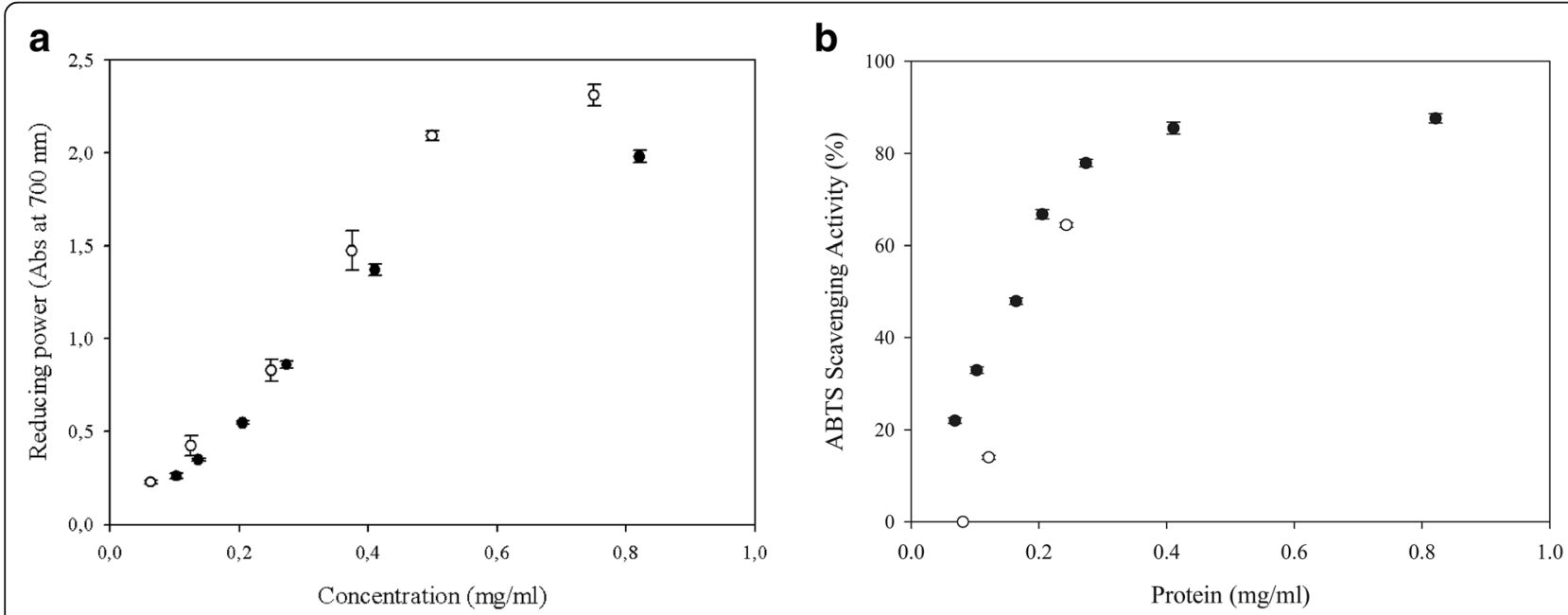

Fig. 5 a Reducing power of the feather protein hydrolysate produced by Bacillus cytotoxicus Oll-15 (black) and ascorbic acid (white). b ABTS scavenging activity (\%) of the feather protein hydrolysates produced by Bacillus cytotoxicus LT-1 (white) and Bacillus cytotoxicus Oll-15 (black) 
The sensitivity of the enzymes under investigation to the protease inhibitors, EDTA and 1,10 phenanthroline, suggests that they belong to the metallo-class of keratinase. Also, the inhibition of Oll-15 extract by Iodoacetamide suggests the presence of free cysteine near the active site of the enzymes [49]. Although most of the keratinases investigated until now can be classified as serine proteases, keratinolytic metalloproteases from the Bacillus spp. have gained prominence. Metalloproteases are from Bacillus sp. P45, Bacillus sp. SCB-3, Bacillus subtilis MTCC (9102), Bacillus polymyxa and B. cereus, Bacillus sp. CSK2, etc. [41, 50-53].

The inhibitory effect of organic solvents on proteases from the Bacillus species has been reported earlier. Methanol, ethanol, and isopropanol inhibited the activity of the protease from Bacillus subtilis KD-N2 by $21 \%$, $38 \%$, and $24 \%$, respectively, while activity of BPKer from Bacillus sp. AD-W was inhibited by $22.4 \%, 44 \%$ and $41.2 \%$, respectively [34, 48]. A stronger inhibition was observed when the alkaline protease BS1 from B. safensis S406 was incubated with methanol and ethanol $(10.2 \%$ and $7.1 \%$ of residual activity, respectively) [54]. Generally, hydrophilic solvents with $\log P$ values below 4.0 are considered extremely toxic e-methanol $(\log P=-0.76$, ethanol $(\log P=-0.24)$ and isopropanol $(\log P=0.28)$ $[54,55]$. Although these solvents are classified as extremely toxic, the keratinolytic enzymes produce by $B$. cytotoxicus strains were slightly inhibited by them.

Metallo-keratinases usually displayed variable metallic ion tolerance. It has been reported that divalent cations help the maintenance of the active site conformation and are important to stabilize the enzyme-substrate complex [56]. $\mathrm{Co}^{+2}$ and $\mathrm{Hg}^{+2}$ inhibited the enzymatic activity on both extracts, with $28-46 \%$ of residual activity (Table 1). The inhibition by heavy metals is commonly observed on hydrolytic enzymes, and the inhibition by $\mathrm{Hg}^{+2}$ may suggest the presence of a free cysteine near the active sites [57].

Most proteases and keratinases produced by bacteria are monomers with molecular weight varying from 14 to $240 \mathrm{kDa}$ [1]. Most common molecular weight from bacterial proteases with keratinolytic activity rounds near 30 $\mathrm{kDa}$ and higher molecular masses were related to metalloproteases from thermophilic microorganisms [56]. Riessen and Antranikian [6] report a keratinase of 135 $\mathrm{kDa}$ produced by Thermoanaerobacter keratinophilus, and Kublanov et al. [7] report a keratinase of $150 \mathrm{kDa}$ produced by Thermoanaerobacter sp. 1004-09. A keratinase of $35 \mathrm{kDa}$ produced by the thermophilic strain Thermoactinomyces sp. YT06 was recently reported by Wang et al. [58].

Keratinolytic proteases from B. cytotoxicus strains demonstrated similar residual activity after the incubation with selected commercial laundry detergents. Paul et al. [59] reported that Paenibacillus woosongensis crude keratinase showed a range of $48.1-70.4 \%$ residual activity under similar treatment conditions. Some ingredients of detergents including fiber brighteners, foam regulators, bleaching agents, re-deposition agents, surfactants, and softening builders have been reported to affect the stability of proteolytic enzymes [60].

It is well known that proteases and keratinases are required in food, biomedical, pharmaceutical, and cosmetic industries. Currently, proteolytic microorganisms with the ability to produce feather protein hydrolysates (FPH) have gained territory because its utilization involves the revalorization of a residue to obtain a byproduct: an animal-food additive [56]. The degradation of the feather on a minimal media can improve the nutritional value of keratinous wastes [56].

The feature that non-reducing power was observed in FPH obtained from B. cytotoxicus LT-1 and that a good reducing power was observed in Oll-15 FPH demonstrated that the composition of proteolytic/keratinolytic cocktails is important when an FPH with bioactive compounds is looking for Oll-15 FPH with $0.27 \mathrm{mg} \cdot \mathrm{ml}^{-1}$ of soluble protein producing an absorbance (Abs $700 \mathrm{~nm}$ ) of 0.86. This value is higher than that reported by Callegaro et al. [61] for an FPH produced by Bacillus sp. C18 during submerged cultivation after $24 \mathrm{~h}$, where 0.15 $\mathrm{mg} \cdot \mathrm{ml}^{-1}$ of soluble protein produced $0.068 \mathrm{Abs} 700 \mathrm{~nm}$; moreover, $3.68 \mathrm{mg} \cdot \mathrm{ml}^{-1}$ of soluble protein (after 7 days of cultivation) produced just 0.318 Abs $700 \mathrm{~nm}$. Similar results were obtained for an FPH produced by Bacillus sp. CL14; after 13 days of cultivation, $3.51 \mathrm{mg} \cdot \mathrm{ml}^{-1}$ of soluble protein produced $0.230 \mathrm{Abs} 700 \mathrm{~nm}$.

The scavenging activity of FPHs from B. cytotoxicus degradation is in concordance with other authors and is even higher. Fontoura et al. [62] reported that FPH (15$25 \mathrm{mg} \cdot \mathrm{ml}^{-1}$ of protein) produced by Chryseobacterium sp. kr6 has 95\% ABTS scavenging activity, while FPH with $3.51 \mathrm{mg} \cdot \mathrm{ml}^{-1}$ of soluble protein present on Bacillus sp. CL14 FPH has $75.95 \%$ ABTS scavenging activity and $\mathrm{FPH}$ with $0.663 \mathrm{mg} \cdot \mathrm{ml}^{-1}$ of soluble protein has $35.23 \%$ ABTS scavenging activity in the case of Bacillus sp. CL33A [61].

The $\mathrm{EC}_{50}$ values were calculated from the dose-response curves, $0.16 \mathrm{mg} \cdot \mathrm{ml}^{-1}$ for $\mathrm{FPH}$ obtained with $B$. cytotoxicus Oll-15 and $0.22 \mathrm{mg} \cdot \mathrm{ml}^{-1}$ for FPH obtained with B. cytotoxicus LT-1. Using ABTS assay, FPHs obtained with Chryseobacterium sp. Kr6 presented lower antioxidant activity $\left(\mathrm{EC}_{50}\right.$ of $16.0-18.3 \mathrm{mg} \cdot \mathrm{ml}^{-1}$, [62]) than the FPH obtained with Bacillus sp. CL18 and lower than those reported here.

Although further studies are required to elucidate the significance of the isolates in the application in biotechnology, this first approach demonstrates that thermotolerant microorganisms are a niche that is needed to be 
investigated in order to find new biocatalysts producing new robust enzymes and bioactive peptides.

\section{Conclusions}

This work represents the first study related to the production and characterization of proteases produced by Bacillus cytotoxicus strains. Bacterial strains studied on this work represent a novel source of proteases with keratinolytic activity, which are of industrial interest. Enzymatic extracts demonstrated to be a cocktail of different proteolytic enzymes of metalloprotease nature that were biochemically characterized.

When the FPHs obtained were assessed for antioxidant activity, it was found that they possess good antioxidant activity demonstrating its potential application as an additive for animal feed formulations. However, this potential application requires further investigations of the safety of FPHs. It is worth mentioning that previous reports $[10,63]$ stand out in that the detection of cytK-1 gene is not a sufficient criterion for identification as cytotoxic strains.

\section{Abbreviations}

FPH: Feather protein hydrolysate; EC50: Half maximal effective concentration; MMM: Minimal mineral media; TCA: Trichloroacetic acid; SDS: Sodium dodecyl sulfate

\section{Acknowledgements}

Not applicable

\section{Authors' contributions}

The isolation, identification, and characterization of Bacillus cytotoxicus strains were performed by IC. She conceived the idea for this work and designed the experiments. IC and BB performed the experiments. The manuscript was written by BB and deeply corrected by IC and SC. The authors have read and approved the manuscript.

\section{Funding}

This work was supported by grants from the National Scientific and Technological Research Council and the National Agency for the Promotion of Science and Technology under Grants number PICT 2018-3194. The research fund from PICT 2018-3194 was utilized for purchasing laboratory reagents; this was done by the administration of Fundación Ciencias Exactas.

\section{Availability of data and materials}

All data generated or analyzed during this study are included in this published article.

\section{Declarations}

Ethics approval and consent to participate

Not applicable

\section{Consent for publication}

Not applicable

\section{Competing interests}

The authors declare that there are no competing interests.
Received: 17 March 2021 Accepted: 9 July 2021

Published online: 22 July 2021

\section{References}

1. Avdiyuk KV, Varvanets A (2019) Keratinolytic enzymes: producers, physical and chemical properties. Application for biotechnology. Biotechnol Acta 12 27-45

2. Verma A, Singh H, Anwar S, Chattopadhyay A, Tiwari KK, Kaur S, Dhilon GS (2017) Microbial keratinases: industrial enzymes with waste management potential. Crit Rev Biotechnol 37(4):476-491. https://doi.org/10.1080/073 88551.2016.1185388

3. Callegaro K, Brandelli A, Daroit DJ (2019) Beyond plucking: feathers bioprocessing into valuable protein hydrolysates. Waste Manag 95:399-415. https://doi.org/10.1016/j.wasman.2019.06.040

4. Friedrich $A B$, Antranikian $G$ (1996) Keratin degradation by Fervidobacterium pennovorans, a novel thermophilic anaerobic species of the order Thermotogales. Appl Environ Microbiol 62(8):2875-2882. https://doi.org/1 0.1128/aem.62.8.2875-2882.1996

5. Nam GW, Lee DW, Lee HS, Lee NJ, Kim BC, Choe EA, Hwang JK, Suhartono MT, Pyun YR (2002) Native feather degradation by Fervidobacterium islandicum AW-1, a newly isolated keratinase-producing thermophilic anaerobe. Arch Microbiol 178(6):538-547. https://doi.org/10.1007/s00203002-0489-0

6. Riessen S, Antranikian G (2001) Isolation of Thermoanaerobacter keratinophilus sp. nov.; a novel thermophilic, anaerobic bacterium with keratinolytic activity. Extremophiles 5(6):399-408. https://doi.org/10.1007/ s007920100209

7. Kublanov I, Perevalova A, Slobodkina G, Lebedinsky A, Bidzhieva S, Kolganova T, Kaliberda E, Rumsh L, Haertle T, Bonch-Osmolovskaya E (2009) Biodiversity of thermophilic prokaryotes with hidrolytic activities in hot springs of Uzon Caldera, Kamchatka (Russia). Appl Environ Microbiol 75(1): 286-291. https://doi.org/10.1128/AEM.00607-08

8. Ionata E, Canganella F, Bianconi G, Benno Y, Sakamoto M, Capasso A, Rossi M, La Cara F (2008) A novel keratinase from Clostridium sporogenes bv. pennavorans bv. nov., a thermotolerant organism isolated from solfataric muds. Microbiol Res 163(1):105-112. https://doi.org/10.1016/j.micres.2006.08. 001

9. Matsui T, Yamada Y, Mitsuya H, Shigeri Y, Yoshida Y, Saito Y, Matsui H, Watanabe K (2009) Sustainable and practical degradation of intact chicken feathers by cultivating a newly isolated thermophilic Meiothermus ruber H328. Appl Microbiol Biotechnol 82(5):941-950. https://doi.org/10.1007/s002 53-009-1880-4

10. Guinebretiere MH, Auger S, Galleron N, Contzen M, De Sarrau B, De Buyser ML, Lamberet G, Fagerlund A, Granum PE, Lereclus D, De Vos P, NguyenThe C, Sorokin A (2013) Bacillus cytotoxicus sp. nov. is a novel thermotolerant species of Bacillus cereus Group occasionally associated with food poisoning. Int J Syst Evol Microbiol 63(Pt_1):31-40. https://doi.org/10.1 099/ijs.0.030627-0

11. Cavello I, Urbieta MS, Cavalitto SF, Donati E (2020) Bacillus cytotoxicus isolated from a pristine natural geothermal area reveals high keratinolytic activity. Microorganisms 8:1-13. https://www.mdpi.com/2076-2607/8/6/796

12. Cavello I, Cavalitto S, Hours R (2012) Biodegradation of a keratin waste and the concomitant production of detergent stable serine proteases from Paecilomyces lilacinus. Appl Biochem Biotechnol 167(5):945-958. https://doi. org/10.1007/s12010-012-9650-7

13. Bradford MM (1976) A rapid and sensitive method for the quantitation of microgram quantities of protein utilizing the principle of protein-dye binding. Anal Biochem 72(1-2):248-254. https://doi.org/10.1016/0003-2 697(76)90527-3

14. García-Carreño FL, Dimes LE, Haard NF (1993) Substrate-gel electrophoresis for composition and molecular weight of proteinases or proteinaceous proteinase inhibitors. Anal Biochem 214(1):65-69. https://doi.org/10.1006/a bio.1993.1457

15. Laemmli UK (1970) Cleavage of structural proteins during the assembly of the head of bacteriophage T4. Nature 227(5259):680-685. https://doi.org/1 0.1038/227680a0

16. Dyballa N, Metzger S (2009) Fast and sensitive colloidal coomassie G-250 staining for proteins in polyacrylamide gels. J Vis Exp (30):e1431. https://doi. org/10.3791/1431

17. Yildirim A, Mavi A, Oktay M, Kara A, Algur O, Bilaloglu V (2000) Comparison of antioxidant and antimicrobial activities of tilia (Tilia argentea Desf ex DC), 
sage (Salvia triloba I.), and black tea (Camellia sinensis) extracts. J Agric Food Chem 48(10):5030-5034. https://doi.org/10.1021/ff000590k

18. Re R, Pellegrini N, Proteggente A, Pannala A, Yang M, Rice-Evans C (1999) Antioxidant activity applying an improved ABTS radical cation decolorization assay. Free Radic Biol Med 26(9-10):1231-1237. https://doi. org/10.1016/50891-5849(98)00315-3

19. Chiacchiarini P, Lavalle L, Giaveno A, Donati E (2010) First assessment of acidophilic microorganisms from geothermal Copahue-Caviahue system. Hydrometallurgy 104(3-4):334-341. https://doi.org/10.1016/j.hydromet.2010. 02.020

20. Urbieta MS, González Toril E, Giaveno MA, Aguilera Bazán A, Donati E (2014) Archeal and bacterial diversity in five different hydrothermal ponds in the Copahue region in Argentina. Syst Appl Microbiol 37(6):429-441. https://doi. org/10.1016/j.syapm.2014.05.012

21. Urbieta MS, González-Toril E, Bazán ÁA, Giaveno MA, Donati E (2015) Comparison of the microbial communities of hot springs waters and the microbial biofilms in the acidic geothermal area of Copahue (Neuqu+ ${ }^{\oplus} \mathrm{n}$, Argentina). Extremophiles 19(2):437-450. https://doi.org/10.1007/s00792-01 5-0729-2

22. Cavello I, Urbieta MS, Segretin AB, Giaveno A, Cavalitto S, Donati ER (2018) Assessment of keratinase and other hydrolytic enzymes in thermophilic bacteria isolated from geothermal areas in Patagonia Argentina. Geomicrobiol J 35(2):156-165. https://doi.org/10.1080/01490451.2017.133 9144

23. Lima MA, Urbieta MS, Donati E (2019) Arsenic-tolerant microbial consortia from sediments of Copahue geothermal system with potential applications in bioremediation. J Basic Microbiol 59(7):680-691. https://doi.org/10.1002/ jobm.201800628

24. Williams CM, Richter CS, Mackenzie JM, Shih JC (1990) Isolation, identification and characterization of a feather-degrading bacterium. Appl Environ Microbiol 56(6):1509-1515. https://doi.org/10.1128/aem.56.6.1509-1 515.1990

25. Manczinger L, Rozs M, Vavolgyi C, Kevei F (2003) Isolation and characterization of a new keratinolytic Bacillus licheniformis strain. World J Microbiol Biotechnol 19(1):35-39. https://doi.org/10.1023/A:1022576826372

26. Rai SK, Konwarh R, Mukherjee AK (2009) Purification, characterization and biotechnological application of an alkaline $\beta$-keratinase produced by Bacillus subtilis RM-01 in solid-state fermentation using chicken-feather as substrate. Biochem Eng J 45(3):218-225. https://doi.org/10.1016/j.bej.2009.04.001

27. Bihari Z, Vidéki E, Mihalik A, Szvetnik Z, Szabó M, Kesseru P, Kiss I (2010) Degradation of native feathers by a novel keratinase-producing, thermophilic lisolate, Brevibacillus thermoruber T1E. Z Naturforsch C 65(1-2): 134-140. https://doi.org/10.1515/znc-2010-1-221

28. Shrinivas D, Naik GR (2011) Characterization of alkaline thermostable keratinolytic protease from thermoalkalophilic Bacillus halodurans JB 99 exhibiting dehairing activity. Int Biodeterior Biodegradation 65(1):29-35. https://doi.org/10.1016/j.ibiod.2010.04.013

29. Bouacem K, Bouanane-Darenfed A, Zarai Jaouadi N, Joseph M, Hacene H, Ollivier B, Fardeau ML, Bejar S, Jaouadi B (2016) Novel serine keratinase from Caldicoprobacter algeriensis exhibiting outstanding hide dehairing abilities. Int J Biol Macromol 86:321-328. https://doi.org/10.1016/jijibiomac.2016.01. 074

30. Sivakumar T, Shankar T, Thangapandian V, Ramasubramanian V (2013) Optimization of cultural condition for keratinase production using Bacillus cereus TS1. Insight Microbiol 3(1):1-8. https://doi.org/10.5567/IMICRO-IK.2 013.1 .8

31. Lateef A, Oloke JK, Gueguim Kana EB, Sobowale BO, Ajao SO, Bello BY (2010) Keratinolytic activities of a new feather-degrading isolate of Bacillus cereus LAU 08 isolated from Nigerian soil. Int Biodeterior Biodegradation 64(2):162-165. https://doi.org/10.1016/j.ibiod.2009.12.007

32. Fakhfakh-Zouari N, Haddar A, Hmidet N, Frikha F, Nasri M (2010) Application of statistical experimental design for optimization of keratinases production by Bacillus pumilus $\mathrm{A} 1$ grown on chicken feather and some biochemical properties. Process Biochem 45(5):617-626. https://doi.org/10.1016/j. procbio.2009.12.007

33. Sahoo DK, Das A, Thatoi H, Mondal KC, Mohapatra PKD (2012) Keratinase production and biodegradation of whole chicken feather keratin by a newly isolated bacterium under submerged fermentation. Appl Biochem Biotechnol 167(5):1040-1051. https://doi.org/10.1007/s12010-011-9527-1

34. Cg C, Js C, Jj Q, Yin Y, Zheng X (2008) Purification and characterization of keratinase from a new Bacillus subtilis strain. J Zhejiang Univ Sci B 9:713-720
35. Abdel-Naby MA, El-Refai HA, Ibrahim MHA (2017) Structural characterization, catalytic, kinetic and thermodynamic properties of Keratinase from Bacillus pumilus FH9. Int J Biol Macromol 105(Pt 1):973-980. https://doi.org/10.1016/ j.ijbiomac.2017.07.118

36. Hamiche S, Mechri S, Khelouia L, Annane R, El Hattab M, Badis A, Jaouadi B (2019) Purification and biochemical characterization of two keratinases from Bacillus amyloliquefaciens S13 isolated from marine brown alga Zonaria tournefortii with potential keratin-biodegradation and hide-unhairing activities. Int J Biol Macromol 122:758-769. https://doi.org/10.1016/j.jpbioma c.2018.10.174

37. Emran MA, Ismail SA, Hashem AM (2020) Production of detergent stable thermophilic alkaline protease by Bacillus licheniformis ALW1. Biocatal Agric Biotechnol 26:101631

38. Jaouadi B, Abdelmalek B, Fodil D, Ferradji FZ, Rekik H, Zara N, Bejar S (2010) Purification and characterization of a thermostable keratinolytic serine alkaline proteinase from Streptomyces sp. strain AB1 with high stability in organic solvents. Bioresour Technol 101(21):8361-8369. https://doi.org/10.1 016/j.biortech.2010.05.066

39. Habbeche A, Saoudi B, Jaouadi B, Haberra S, Kerouaz B, Boudelaa M, Badis A, Ladjama A (2014) Purification and biochemical characterization of a detergent-stable keratinase from a newly thermophilic actinomycete Actinomadura keratinilytica strain Cpt29 isolated from poultry compost. J Biosci Bioeng 117(4):413-421. https://doi.org/10.1016/j.jbiosc.2013.09.006

40. Abdel-Fattah AM, El-Gamal MS, Ismail SA, Emran MA, Hashem AM (2018) Biodegradation of feather waste by keratinase produced from newly isolated Bacillus licheniformis ALW1. J Genet Eng Biotechnol 16(2):311-318. https://doi.org/10.1016/j.jgeb.2018.05.005

41. Daroit DJ, Correa AP, Brandelli A (2011) Production of keratinolytic proteases through bioconversion of feather meal by the Amazonian bacterium Bacillus sp. P45. Int Biodeterior Biodegradation 65(1):45-51. https://doi.org/1 0.1016/j.ibiod.2010.04.014

42. Bhari R, Kaur M, Singh RS (2019) Thermostable and halotolerant keratinase from Bacillus aerius NSMk2 with remarkable dehairing and laundary applications. J Basic Microbiol 59(6):555-568. https://doi.org/10.1002/jobm.2 01900001

43. Tork SE, Shahein YE, El-Hakim AE, Abdel-Aty AM, Aly MM (2013) Production and characterization of thermostable metallo-keratinase from newly isolated Bacillus subtilis NRC 3. Int J Biol Macromol 55:169-175. https://doi.org/10.101 6/j.jpbiomac.2013.01.002

44. Collins T, Meuwis MA, Gerday C, Feller G (2003) Activity, stability and flexibility in glycosidases adapted to extreme thermal environments. J Mol Biol 328(2):419-428. https://doi.org/10.1016/S0022-2836(03)00287-0

45. Hashem AM, Abdel-Fattah A, Ismail S, El-Gamal M, Esawy M, Emran MA (2018) Optimization, characterization and thermodynamic studies on $B$. licheniformis ALW1 keratinase. Egypt J Chem 61:591-607

46. Hammami A, Fakhfakh N, Abdelhedi O, Nasri M, Bayoudh A (2018) Proteolytic and amylolytic enzymes from a newly isolated Bacillus mojavensis SA: characterization and applications as laundry detergent additive and in leather processing. Int J Biol Macromol 108:56-68. https:// doi.org/10.1016/j.jijbiomac.2017.11.148

47. Ferrareze PAG, Correa APF, Brandelli A (2016) Purification and characterization of a keratinolytic protease produced by probiotic Bacillus subtilis. Biocatal Agric Biotechnol 7:102-109. https://doi.org/10.1016/.bcab.2016.05.009

48. Gegeckas A, Simkute A, Gudiukaité R, Citavicius DJ (2018) Characterization and application of keratinolytic paptidases from Bacillus spp. Int J Biol Macromol 113:1206-1213. https://doi.org/10.1016/j.jibiomac.2018.03.046

49. Thys RCS, Brandelli A (2006) Purification and properties of a keratinolytic metalloprotease from Microbacterium sp. J Appl Microbiol 101(6):1259-1268. https://doi.org/10.1111/j.1365-2672.2006.03050.x

50. Lee H, Suh DB, Hwang JH, Suh HJ (2002) Characterization of a kerationlytic metalloprotease from Bacillus sp. SCB-3. Appl Biochem Biotechnol 97(2): 123-133. https://doi.org/10.1385/ABAB:97:2:123

51. Balaji S, Senthil Kumar M, Karthikeyan R, Kumar R, Kirubanandan S, Sridhar R, Sehgal PK (2008) Purification and characterization of an extracellular keratinase from a hornmeal-degrading Bacillus subtilis MTCC (9102). World I Microbiol Biotechnol 24(1 1):2741-2745. https://doi.org/10.1007/s11274-008-9782-7

52. Laba W, Rodziewicz A (2010) Keratinolytic potential of feather-degrading Bacillus polymyxa and Bacillus cereus. Pol J Environ Stud 19:371-378

53. Nnolim NE, Nwodo UU (2020) Bacillus sp. CSK2 produced thermostable alkaline keratinase using agro-wastes: keratinolytic enzyme characterization. BMC Biotechnol 20:65 
54. Mhamdi S, Bkhairia I, Nasri R, Mechichi T, Nasri M, Kamoun AS (2017) Evaluation of the biotechnological potential of a novel purified protease BS1 from Bacillus safensis S406 on the chitin extraction and detergent formulation. Int J Biol Macromol 104(Pt A):739-747. https://doi.org/10.1016/j. ijbiomac.2017.06.062

55. Rahman RNZRA, Mahamad S, Salleh AB, Basri M (2007) A new organic solvent tolerant protease from Bacillus pumilus 115b. J Ind Microbiol Biotechnol 34(7):509-517. https://doi.org/10.1007/s10295-007-0222-8

56. Brandelli A, Daroit DJ, Riffel A (2010) Biochemical features of microbial keratinases and their production and applications. Appl Microbiol Biotechnol 85(6):1735-1750. https://doi.org/10.1007/s00253-009-2398-5

57. More S, Prakash S, Umashankar S, Vishwakarma J (2013) Purification and properties of a novel fungal alkaline keratinase from Cunninghamella echinulata. Turkish J Biochem 38(1):68-74. https://doi.org/10.5505/tjb.2013.3 7928

58. Wang L, Qian Y, Cao Y, Huang Y, Chang Z, Huang H (2017) Production and characterization of keratinolytic proteases by a chicken feather-degrading thermophilic strain, Thermoactinomyces sp. YT06. J Microbiol Biotechnol 27(12):2190-2198. https://doi.org/10.4014/jmb.1705.05082

59. Paul T, Das A, Mandal A, Halder SK, Jana A, Maity C, DasMohapatra PK, Pati BR, Mondal KC (2014) An efficient cloth cleaning properties of a crude keratinase combined with detergent: towards industrial viewpoint. J Clean Prod 66:672-684. https://doi.org/10.1016/j.jclepro.2013.10.054

60. Ramakrishna Reddy M, Sathi Reddy K, Ranjita Chouhan Y, Bee H, Reddy G (2017) Effective feather degradation and keratinase production by Bacillus pumilus GRK for its application as bio-detergent additive. Bioresour Technol 243:254-263. https://doi.org/10.1016/j.biortech.2017.06.067

61. Callegaro K, Welter N, Daroit DJ (2018) Feathers as bioresource: microbia conversion into bioactive protein hydrolysates. Process Biochem 75:1-9. https://doi.org/10.1016/j.procbio.2018.09.002

62. Fontoura R, Daroit DJ, Correa APF, Meira SMM, Mosquera M, Brandelli A (2014) Production of feather hydrolysates with antioxidant, angiotensin-I converting enzyme- and dipeptidyl peptidase-IV-inhibitory activities. New Biotechnol 31(5):506-513. https://doi.org/10.1016/j.nbt.2014.07.002

63. Fagerlund A, Brillard J, First R, Guinebretiere MH, Granum PE (2007) Toxin production in a rare and genetically remote cluster of strains of the Bacillus cereus group. BMC Microbiol 7:43

\section{Publisher's Note}

Springer Nature remains neutral with regard to jurisdictional claims in published maps and institutional affiliations.

\section{Submit your manuscript to a SpringerOpen ${ }^{\circ}$ journal and benefit from:}

- Convenient online submission

- Rigorous peer review

- Open access: articles freely available online

- High visibility within the field

- Retaining the copyright to your article

Submit your next manuscript at $\boldsymbol{\nabla}$ springeropen.com 